\title{
Nd ISOTOPIC VARIATIONS and PETROGENETIC MODELS
}

\author{
D. J. DePaolo and G. J. Wasserburg \\ Lunatic Asylum, Div. Geological and Planetary Sciences, California Institute of Technology, Pasadena, California 91125
}

Abstract: The decay of ${ }^{147} \mathrm{Sm}$ to ${ }^{143} \mathrm{Nd}$ allows ${ }^{143} \mathrm{Nd} /{ }^{144} \mathrm{Nd}$ to be used to trace $\mathrm{Sm} / \mathrm{Nd}$ fractionation in long time-scale geologic processes. ${ }^{143} \mathrm{Nd} /{ }^{144} \mathrm{Nd}$ has been measured in terrestrial rock samples of different ages to establish the characteristics of Nd isotopic evolution in the crust and mantle. The evolution of ${ }^{143} \mathrm{Nd} /{ }^{144} \mathrm{Nd}$ in the mantle indicates $\mathrm{Sm} / \mathrm{Nd}$ essentially equal to that of chondrites, and implies a chondritic REE distribution for the earth. Variations in ${ }^{143} \mathrm{Nd} /{ }^{144} \mathrm{Nd}$ do exist in the mantle, however, indicating $\mathrm{Sm} / \mathrm{Nd}$ heterogeneity and the existence of distinct mantle reservoirs with characteristic ${ }^{143} \mathrm{Nd} /{ }^{144} \mathrm{Nd}$. ${ }^{143} \mathrm{Nd} /{ }^{144} \mathrm{Nd}$ in average crustal rocks today is much lower than found in recent mantle samples and reflects their age and low $\mathrm{Sm} / \mathrm{Nd}$. Oceanic tholeiites and alkali basalt are derived from sources with $\mathrm{Sm} / \mathrm{Nd}$ which has been $5-10 \%$ greater than chondritic over the age of the earth. Alkali basalt can not be derived from mantle reservoirs which have been light REEenriched for long times.

Long-lived, naturally-occurring radioisotopes are important not only in the measurement of absolute time, but also as indicators of chemical processes involved in rock formation. ${ }^{147} \mathrm{Sm}$ decays to ${ }^{143} \mathrm{Nd}$ with a half-life of $1.06 \times 10^{11}$ years. $\mathrm{Sm}$ and $\mathrm{Nd}$ are even-numbered light lanthanide elements, so their cosmic abundances and chemical properties are similar. But, $\mathrm{Sm} / \mathrm{Nd}$ fractionation is commonly observed in rocks and minerals, and is a sensitive indicator of fractionation in the light rare-earth elements (REE). The use of Sm-Nd as a dating method was pioneered by Lugmair (1974) and Lugmair et al. (1975 $a, b, c, d)$ who determined ages of the Juvinas and Stannern achondrites and one lunar basalt. The purpose of this study is to investigate the isotopic composition of Nd in selected terrestrial rocks to gain information about its implications for petrogenesis and the history of the earth's crust and mantle. The potential usefulness of the Sm-Nd system for the dating of terrestrial rocks is also made manifest. A symbolism is introduced which may be useful in presentation and interpretation of the data.

As discussed by Lugmair (1974) the ratio ${ }^{143} \mathrm{Nd} /{ }^{144} \mathrm{Nd}$ is an indicator of changes in the relative abundance of ${ }^{143} \mathrm{Nd}$ due to ${ }^{147} \mathrm{Sm}$ decay. For formation and chemical evolution of a planet, the growth of ${ }^{14^{3}} \mathrm{Nd} /{ }^{144} \mathrm{Nd}$ with time in various reservoirs may be shown schematically (Figure 1). At $\mathrm{T}_{C}$ a planet condenses from the solar nebula (SN). The rate of ${ }^{143} \mathrm{Nd} /{ }^{144} \mathrm{Nd}$ growth in the bulk planet may be different from the growth rate in the solar nebula due to a change in $\mathrm{Sm} / \mathrm{Nd}$ occurring during condensation (Boynton, 1975). If a reservoir with $\mathrm{Sm} / \mathrm{Nd}=0$ were isolated at $\mathrm{T}_{\mathrm{c}}$, $\mathrm{I}_{\mathrm{c}}$ would record ${ }^{143} \mathrm{Nd} /{ }^{144} \mathrm{Nd}$ at the time of condensation. If the planet remains a closed system with respect to $\mathrm{Sm}$ and $\mathrm{Nd}$ subsequent to $\mathrm{T}_{\mathrm{c}}$, the evolution of its average ${ }^{143} \mathrm{Nd} /{ }^{144} \mathrm{Nd}$ will be described by a line whose slope is proportional to its average $\mathrm{Sm} / \mathrm{Nd}$. The bulk planet is herein termed a "uniform reservoir" (UR) and the growth of ${ }^{143} \mathrm{Nd} / 1^{14} \mathrm{Nd}$ in UR as a function of time is the curve I UR (T). The value of ${ }^{13^{3}} \mathrm{Nd} /{ }^{144} \mathrm{Nd}$ in $U R$ today is defined as I UR $(0) .{ }^{143} \mathrm{Nd} /{ }^{144} \mathrm{Nd}$ in UR at any time $\mathrm{T}$ in the past is given by

$$
I_{U R}(T)=I_{U R}(0)-\left(\frac{{ }^{147} \mathrm{Sm}}{{ }^{144} \mathrm{Nd}}\right)_{U R}^{0}\left(e^{\lambda T}-1\right) \text {, }
$$

where $\left({ }^{147} \mathrm{Sm} / 1^{144} \mathrm{Nd}\right)_{\mathrm{UR}}^{0}$ is that in UR today and $\lambda=6.54 \mathrm{x}$ $10^{-12} \mathrm{yr}^{-1}$. If a rock is derived from this average reservoir at time $T$, its initial ${ }^{143} \mathrm{Nd} /{ }^{144} \mathrm{Nd}$ would be $\mathrm{I}_{\mathrm{UR}}(\mathrm{T})$.

Chemical differentiation in the planet subsequent to $T_{c}$ will result in reservoirs with different $\mathrm{Sm} / \mathrm{Nd}$. The $\mathrm{Sm} / \mathrm{Nd}$ of a reservoir can be expressed relative to UR in terms of a $\mathrm{Sm} / \mathrm{Nd}$ Copyright 1976 by the American Geophysical Union. enrichment factor $f$, where $f=\left\{\frac{(\mathrm{Sm} / \mathrm{Nd})_{\mathrm{Res}}}{(\mathrm{Sm} / \mathrm{Nd})_{\mathrm{UR}}}-1\right\}$. If at a time $T_{1} \leqslant T_{C}$ a secondary reservoir $A$ is isolated from $U R$ with initial value $I_{1}$ and $\mathrm{f}<0,{ }^{143} \mathrm{Nd} /{ }^{144} \mathrm{Nd}$ in this reservoir would evolve from $\left(T_{1}, I_{1}\right)$ along a line of lower slope to the value $R_{A}$ observed today. Similarly ${ }^{143} \mathrm{Nd} / 1^{144} \mathrm{Nd}$ in a reservoir $\mathrm{B}$, isolated from UR at $T_{1}$ with $>0$ would evolve along a steeper trajectory to $\mathrm{RB}_{\mathrm{B}}$ today. For rocks of zero age the $\mathrm{Nd}$ isotopic composition of the source region is identical to that measured in the rock. ${ }^{143} \mathrm{Nd} /{ }^{144} \mathrm{Nd}$ in source regions of old rocks is found by determination of the initial ${ }^{143} \mathrm{Nd} /{ }^{144} \mathrm{Nd}$ (I). This can be obtained from an internal isochron or, if the age is known, from the measured ${ }^{143} \mathrm{Nd} / 1^{144} \mathrm{Nd},{ }^{147} \mathrm{Sm} /{ }^{144} \mathrm{Nd}$, and the age $\mathrm{T}$ :

$$
I=\left(\frac{143 \mathrm{Nd}}{144 \mathrm{Nd}}\right)_{\text {meas }}-\left(\frac{1{ }^{14} \mathrm{Sm}}{{ }^{144} \mathrm{Nd}}\right)_{\text {meas }}\left(\mathrm{e}^{\lambda \mathrm{T}}-1\right) .
$$

As shown in Figure 1, two rocks of the same age $T_{1}$, but different initial $I_{1}$ and $I_{1}^{\prime}$, must have been derived from distinct parent reservoirs.

In a reservoir whose $\mathrm{Sm} / \mathrm{Nd}$ is equal to that in chondritic meteorites (0.31) (Masuda et al., 1973), ${ }^{143} \mathrm{Nd} /{ }^{144} \mathrm{Nd}$ will increase by $1.13 \%$ in $4.5 \mathrm{AE}$. REE abundance patterns in various rocks indicate that sufficient variation in $\mathrm{Sm} / \mathrm{Nd}$ exists so that initial ${ }^{143} \mathrm{Nd} /{ }^{144} \mathrm{Nd}$ may be used to distinguish different source regions. Some of the isotopic patterns can be anticipated from the extensive experimental and theoretical studies of REE abundances and fractionation patterns. (cf. Haskin et al., 1966a.)

Analytical Procedure and Data. In general, the chemical and mass spectrometric procedures used closely follow those which have been used here for the past eight years for Gd and $\mathrm{Sm}$. Separation of $\mathrm{Sm}$ and $\mathrm{Nd}$ was accomplished using the procedure described for Gd separation by Eugster et al, (1970), with slight modifications. Sm and Nd were eluted from Dowex AG 50W-X4 cation exchange resin using 0.2M 2-Methyllactic

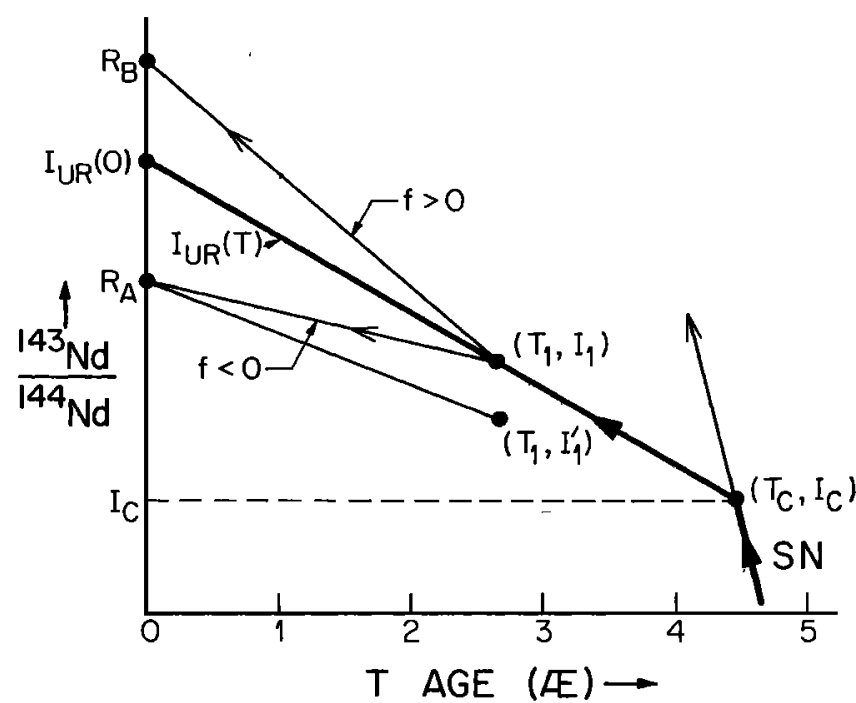

Fig. 1: Schematic representation of the evolution of ${ }^{143} \mathrm{Nd} /{ }^{144} \mathrm{Nd}$ with time in the solar nebula (SN) and in a hypothetical planetary object condensed at $T_{c}$. The growth rate of ${ }^{143} \mathrm{Nd} /{ }^{144} \mathrm{Nd}$ is proportional to $\mathrm{Sm} / \mathrm{Nd}$. $\mathrm{f}$ is the $\mathrm{Sm} / \mathrm{Nd}$ enrichment factor relative to UR. 
Table 1: Normalized Nd isotope ratios ${ }^{a}$

\begin{tabular}{|c|c|c|c|c|c|}
\hline Sample & $142 / 144$ & $143 / 144$ & $145 / 144$ & $146 / 144$ & $148 / 144$ \\
\hline$1 1 \longdiv { 3 0 3 1 }$ & $\begin{array}{r}1.13821 \\
\pm 8\end{array}$ & $\begin{array}{r}\overline{0.512115} \\
\pm 40\end{array}$ & $\begin{array}{r}\overline{0.348952} \\
\pm 30\end{array}$ & $\begin{array}{r}\overline{0.724082} \\
\pm 35\end{array}$ & $\begin{array}{r}\overline{0.243066} \\
\pm 30\end{array}$ \\
\hline 111240 & $\begin{array}{r}1.13828 \\
\pm 5\end{array}$ & $\begin{array}{r}0.512361 \\
\pm 22\end{array}$ & $\begin{array}{r}0.348975 \\
\pm 18\end{array}$ & $\begin{array}{r}0.724113 \\
\pm 26\end{array}$ & $\begin{array}{r}0.243091 \\
\pm 26\end{array}$ \\
\hline 113152 & $\begin{array}{r}1.13823 \\
\pm 7\end{array}$ & $\begin{array}{r}0.512280 \\
\pm 35\end{array}$ & $\begin{array}{r}0.348950 \\
\pm 42\end{array}$ & b & $\begin{array}{r}0.243112 \\
\pm 43\end{array}$ \\
\hline BCR-1 & $\begin{array}{r}1.13827 \\
\pm 4\end{array}$ & $\begin{array}{r}0.511839 \\
\pm 22\end{array}$ & $\begin{array}{r}0.348977 \\
\pm 19\end{array}$ & $\begin{array}{r}0.724088 \\
\pm 36\end{array}$ & $\begin{array}{r}0.243070 \\
\pm 19\end{array}$ \\
\hline Khibina Ap. & $\begin{array}{r}1.13827 \\
\pm 4\end{array}$ & $\begin{array}{r}0.511862 \\
\pm 17\end{array}$ & $\begin{array}{r}0.348970 \\
\pm 19\end{array}$ & $\begin{array}{r}0.724116 \\
\pm 30\end{array}$ & $\begin{array}{r}0.243082 \\
\pm 20\end{array}$ \\
\hline NAS-216D & $\begin{array}{r}1.13823 \\
\pm 4\end{array}$ & $\begin{array}{r}0.511101 \\
\pm 27\end{array}$ & $\begin{array}{r}0.348968 \\
\pm 38\end{array}$ & $\begin{array}{r}0.724086 \\
\pm 54\end{array}$ & $\begin{array}{r}0.243110 \\
\pm 29\end{array}$ \\
\hline RHO-1D & $\begin{array}{r}1.13819 \\
\pm 15\end{array}$ & $\begin{array}{r}0.510994 \\
\pm 48\end{array}$ & $\begin{array}{r}0.348943 \\
\pm 48\end{array}$ & $\begin{array}{r}0.724079 \\
\pm 113\end{array}$ & $\begin{array}{r}0.243089 \\
\pm 34\end{array}$ \\
\hline RN3-D(TR) & $\begin{array}{r}1.13830 \\
\pm 8\end{array}$ & $\begin{array}{r}0.510245 \\
\pm 31\end{array}$ & $\begin{array}{r}0.348977 \\
\pm 42\end{array}$ & $\begin{array}{r}0.724139 \\
\pm 58\end{array}$ & $\begin{array}{r}0.243072 \\
\pm 38\end{array}$ \\
\hline RN3-D(TR) & $\begin{array}{r}1.13821 \\
\pm 9\end{array}$ & $\begin{array}{r}0.510234 \\
\pm 37\end{array}$ & $\begin{array}{r}0.348913 \\
\pm 46\end{array}$ & b & $\begin{array}{r}0.243065 \\
\pm 65\end{array}$ \\
\hline RN3 Ap. & $\begin{array}{r}1.13825 \\
\pm 5\end{array}$ & $\begin{array}{r}0.511343 \\
\pm 23\end{array}$ & $\begin{array}{r}0.348965 \\
\pm 27\end{array}$ & $\begin{array}{r}0.724122 \\
\pm 31\end{array}$ & $\begin{array}{r}0.243084 \\
\pm 28\end{array}$ \\
\hline OGG128,10D & $\begin{array}{r}1.13826 \\
\pm 6\end{array}$ & $\begin{array}{r}0.510026 \\
\pm 30\end{array}$ & $\begin{array}{r}0.348965 \\
\pm 17\end{array}$ & $\begin{array}{r}0.724103 \\
\pm 44\end{array}$ & $\begin{array}{r}0.243089 \\
\pm 22\end{array}$ \\
\hline NN1 & $\begin{array}{r}1.13829 \\
\pm 6\end{array}$ & $\begin{array}{r}0.510306 \\
\pm 19\end{array}$ & $\begin{array}{r}0.348952 \\
\pm 28\end{array}$ & $\begin{array}{r}0.724091 \\
\pm 43\end{array}$ & $\begin{array}{r}0.243080 \\
\pm 30\end{array}$ \\
\hline NN1 & $\begin{array}{r}1.13829 \\
\pm 5\end{array}$ & $\begin{array}{r}0.510329 \\
\pm 21\end{array}$ & $\begin{array}{r}0.348978 \\
\pm 15\end{array}$ & $\mathrm{~b}$ & $\begin{array}{r}0.243091 \\
\pm 17\end{array}$ \\
\hline $\mathrm{NN} 2$ & $\begin{array}{r}1.13826 \\
\pm 3\end{array}$ & $\begin{array}{r}0.511132 \\
\pm 16\end{array}$ & $\begin{array}{r}0.348946 \\
\pm 13\end{array}$ & $\begin{array}{r}0.724115 \\
\pm 20\end{array}$ & $\begin{array}{r}0.243061 \\
\pm 14\end{array}$ \\
\hline NN2 & $\begin{array}{r}1.13827 \\
\pm 6\end{array}$ & $\begin{array}{r}0.511148 \\
\pm 31\end{array}$ & $\begin{array}{r}0.349009 \\
\pm 17\end{array}$ & $\begin{array}{r}0.724156 \\
\pm 45\end{array}$ & $\begin{array}{r}0.243092 \\
\pm 31\end{array}$ \\
\hline NN2 & $\begin{array}{r}1.13824 \\
\pm 9\end{array}$ & $\begin{array}{r}0.511124 \\
\pm 18\end{array}$ & $\begin{array}{r}0.348993 \\
\pm 26\end{array}$ & b & $\begin{array}{r}0.243074 \\
\pm 33\end{array}$ \\
\hline
\end{tabular}

a Normalized to ${ }^{150} \mathrm{Nd} /{ }^{142} \mathrm{Nd}=0.2096$, errors are $2 \sigma$ mean. ${ }^{6}$ Spiked with $150 \mathrm{Nd}$ and normalized to ${ }^{146} \mathrm{Nd} /{ }^{142} \mathrm{Nd}=0.636155$

acid with $\mathrm{pH}$ adjusted to 4.60. Total procedural blank for Nd was $10^{-10} \mathrm{gm}$. Nd was loaded in $1.0 \mathrm{~N} \mathrm{HCl}$ onto a single flat Re ribbon and oxidized. $\mathrm{Nd}$ isotopic ratios were measured on the Lunatic I mass spectrometer (Wasserburg et al., 1969), as $\mathrm{NdO}^{+}$. The ion beam intensity at mass $160\left({ }^{144} \mathrm{Nd}^{16} \mathrm{O}\right)$ was $10^{-11} \mathrm{~A}$ at filament temperatures between $1220^{\circ}$ and $1280^{\circ} \mathrm{C}$. Ion beam intensity ratios were calculated relative to mass 160 . At each mass the high zero, peak and low zero are measured with an integration time of $1 \mathrm{sec}$ at each position. Data is taken in sets of 10 mass scans, averaged; corrected for oxygen and then discrimination. The effect of peak tails on zeros was assessed by measuring the zeros with beam on and beam off. The background offset is less than $0.005 \%$ of the peak intensity for all isotopes. Oxygen corrections were made using the composition by Nier (1950). Mass discrimination corrections were made by normalizing to $150 \mathrm{Nd} / /^{142} \mathrm{Nd}=0.2096$, the average measured value in several mass spectrometer runs. In a typical run of 200 ratios, $1 \sigma$ is $0.01 \%$ and $2 \sigma$ mean is $0.005 \%$. Possible spectral interferences were monitored by scanning at high sensitivity from mass 125 to mass 200 . Peaks could be detected representing $\mathrm{LaO}^{+}$and $\mathrm{GdO}^{+}$at intensities $<1.5 \times 10^{-16} \mathrm{~A}$ and $\mathrm{SmO}^{+}$at $10^{-15} \mathrm{~A}$. Occasionally $\mathrm{Ba}^{+}$was detected $\left(<10^{-15} \mathrm{~A}\right)$. No other peaks were observed at a detection limit of $2.5 \times 10^{-17} \mathrm{~A}$. Interference from $\mathrm{SmO}^{+}$ions is corrected by monitoring the signal at mass $170\left({ }^{154} \mathrm{Sm}^{16} \mathrm{O}\right)$. The net correction to ${ }^{14}{ }^{3} \mathrm{Nd} / /^{144} \mathrm{Nd}$ when the signal at mass 170 is $0.01 \%$ of the 160 signal is only $4 \times 10^{-4} \%$. Isotopic measurements were made on spiked and unspiked aliquants which were passed through chemistry. Sm and Nd concentrations were determined on the same aliquant. Internal consistency of isotopic measurements is shown by agreement of all isotope ratios from different samples and from spiked and unspiked runs on the same sample. Reproducibility is demonstrated by repeat runs on normals. Nd isotopic data are given in Table 1 , and are the first high precision $\mathrm{Nd}$ abundances obtained using modern techniques.

Data representation. Because of the variations in ${ }^{14}{ }^{3} \mathrm{Nd} /{ }^{144} \mathrm{Nd}$ are small, data will be presented normalized to a uniform reservoir (UR) as described above. This is a somewhat different approach than has been used for $\mathrm{Rb}-\mathrm{Sr}$, where there are large variations of ${ }^{87} \mathrm{Sr} /{ }^{86} \mathrm{Sr}$ and there is no clearly defined, meaningful reference reservoir representative of the earth. $143 \mathrm{Nd} /{ }^{144} \mathrm{Nd}$ measured in a sample today is given as fractional deviations from $I_{U R}(0)$ in parts in $10^{4}\left(\epsilon_{0}^{U R}\right)$ :

$$
\epsilon_{0}^{\mathrm{UR}}=\left[\frac{\left({ }^{143} \mathrm{Nd} / 144 \mathrm{Nd}\right)_{\text {meas }}}{\mathrm{I}_{\mathrm{UR}}(0)}-1\right] \times 10^{4} .
$$

Similarly, the initial ${ }^{143} \mathrm{Nd} /{ }^{144} \mathrm{Nd}$ (I) for a sample of age $\mathrm{T}$ is presented as the deviation of $I$ from $I_{U R}(T)$ in parts in $10^{4}$ $\left(\epsilon_{\text {I }}^{\text {UR }}\right)$ :

$$
\epsilon_{\mathrm{I}}^{\mathrm{UR}}(\mathrm{T})=\left[\frac{\mathrm{I}_{\text {sample }}}{\mathrm{I}_{\mathrm{UR}}(\mathrm{T})}-1\right] \times 10^{4} \approx \epsilon_{0}^{\mathrm{UR}}-\mathrm{f}_{\mathrm{R}} \mathrm{QT},
$$

where $f_{R}$ is the $\mathrm{Sm} / \mathrm{Nd}$ enrichment in the rock relative to $U R$ and $\mathrm{Q} \equiv \frac{\lambda\left({ }^{147} \mathrm{Sm} / 1^{14} \mathrm{Nd}\right)_{\mathrm{UR}} \cdot 10^{4}}{\mathrm{I}_{\mathrm{UR}}(0)}$ is a constant. Thus a sample with a present value of $\epsilon_{0}^{\mathrm{UR}}$ which was derived from UR T years ago would have $\epsilon_{\mathrm{I}}^{\mathrm{UR}}(\mathrm{T})=0$. A value of $\epsilon_{\mathrm{I}}^{\mathrm{UR}}(\mathrm{T})$ different from zero indicates that the source region was fractionated relative to UR prior to $T$. The average fractionation factor for the source $\left\langle f_{S}\right\rangle$ over the time interval $T_{\mathrm{C}^{-}} T$ is related to $\epsilon_{\mathrm{I}}^{\mathrm{UR}}$ by: $\left\langle f_{S}\right\rangle\left(T_{c}-T\right) \equiv \frac{\epsilon_{I}^{U R}}{Q}\left(\equiv f^{*} T^{*}\right)$. This information will be presented in terms of a generalized quantity $f^{*} T^{*}$, where $T^{*}$ represents the amount of time necessary to produce the deviation $\epsilon_{\mathrm{I}}^{\mathrm{UR}}$ with an enrichment factor $f^{*}$. From $\left\langle f_{S}\right\rangle$ and the measured $\mathrm{Sm} / \mathrm{Nd}$ fractionation of the sample relative to $\operatorname{UR}\left(\mathrm{f}_{\mathrm{R}}\right)$, one can calculate the $\mathrm{Sm} / \mathrm{Nd}$ fractionation factor for the sample relative to the source $(\mathrm{g})$ assuming a simple two-stage history:

$1+\mathrm{g}=1+\mathrm{f}_{\mathrm{R}} / 1+\left\langle\mathrm{f}_{\mathrm{S}}\right\rangle$. A similar theoretical factor $(\mathrm{g} \mathrm{TH})$ can be calculated using $\mathrm{Sm}$ and $\mathrm{Nd}$ mineral/melt distribution coefficients for an assumed source mineralogy and degree of melting. Consideration of both $\mathbf{g}_{\mathrm{TH}}$ and $\mathrm{g}$ allows the construction of more rigidly constrained models for the history of the sample and source than would be possible by either concentration or isotopic studies alone.

The above discussion of fractionation in source regions could have been made in terms of model ages (Wasserburg and Papanastassiou, 1975), as is normally done for Rb-Sr. The model age

$$
\mathrm{T}_{M}=\frac{1}{\lambda} \ln \left[1+\frac{\left({ }^{143} \mathrm{Nd} /{ }^{144} \mathrm{Nd}\right)_{\text {meas }}-\mathrm{I}_{\mathrm{c}}}{\left({ }^{147} \mathrm{Sm} /{ }^{144} \mathrm{Nd}\right)_{\text {meas }}}\right]
$$

Model ages give a strict upper limit to the time of last major equilibration of a system, but are most powerful where parentdaughter fractionation is large. For small fractionations, $T_{M} \approx T_{c}$ and the usefulness of model ages may be diminished. Therefore, we have tended to emphasize here the divergence of secondary

\begin{tabular}{|c|c|c|c|c|c|}
\hline Sample & $\begin{array}{l}\text { Age } \\
\text { (AE) }\end{array}$ & $\frac{147 \mathrm{Sm}}{144 \mathrm{Nd}}$ & $\epsilon_{0}^{\text {CHUR }}$ & $\epsilon_{\mathrm{I}}^{\text {CHUR }}$ & $\begin{array}{r}f^{*} T^{*} \\
\left(10^{8} \mathrm{yr}\right. \\
\end{array}$ \\
\hline 113031 (MORB) & 0 & $0.1163 \pm 3$ & $+5.4 \pm 0.8$ & $+5.4 \pm 0.8$ & 2.2 \\
\hline 111240 (MORB) & 0 & $0.204 \pm 4$ & $+10.3 \pm 0.4$ & $+10.3 \pm 0.4$ & 4.2 \\
\hline 113152 (Alk.Ba.) & 0 & $0.2109 \pm 6$ & $+8.7 \pm 0.7$ & $+8.7 \pm 0.7$ & 3.5 \\
\hline BCR (Cont. Ba.) & 0 & $0.14^{b}$ & $+0.1 \pm 0.4$ & $+0.1 \pm 0.4$ & 0.0 \\
\hline Khibina Ap. & $0.29^{d}$ & $0.0950 \pm 3$ & $+0.5 \pm 0.3$ & $+3.7 \pm 0.3$ & 1.5 \\
\hline NAS(Shale) & $' 0^{\prime}$ & $0.12^{c}$ & $-14.4 \pm 0.5$ & $-14.4 \pm 0.5$ & -5.8 \\
\hline RHO (Gt. Dyke) & $2.53^{\mathrm{e}}$ & $0.145 \pm 1$ & $-16.5 \pm 1.0$ & $-0.8 \pm 2.0$ & -0.3 \\
\hline RN3 (Grd.) & $2.65^{f}$ & $0.0996 \pm 3$ & $-31.2 \pm 0.6$ & $+0.6 \pm 1.4$ & 0.2 \\
\hline OGG (Amitsoq) & $3.59 \mathrm{~g}$ & $0.118 \pm 1$ & $-35.4 \pm 0.6$ & $-0.7 \pm 1.7$ & -0.3 \\
\hline NN1 & - & - & $-29.7 \pm 0.4$ & - & - \\
\hline NN2 & - & - & $-13.8 \pm 0.3$ & - & - \\
\hline CHUR $^{\mathrm{a}}$ & all $\mathrm{T}$ & $0.1936^{h}$ & 0 & 0 & 0 \\
\hline
\end{tabular}
growth curves from a primary reference curve. However, iso-

Table 2: Nd evolutionary parameters

${ }^{\text {a CHUR }} \equiv$ Chondritic uniform reservoir; ${ }^{143} \mathrm{Nd} /{ }^{144} \mathrm{Nd}$ in CHUR today $=$ 0.511836 (Lugmair, pers. comm.) ${ }^{b}$ Approximate value from literature. chaskin et al. (1966b). ${ }^{d}$ Gerasimovsky et al (1974). 'Davies et al. (1970).

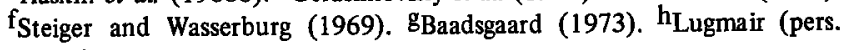
comm.) 


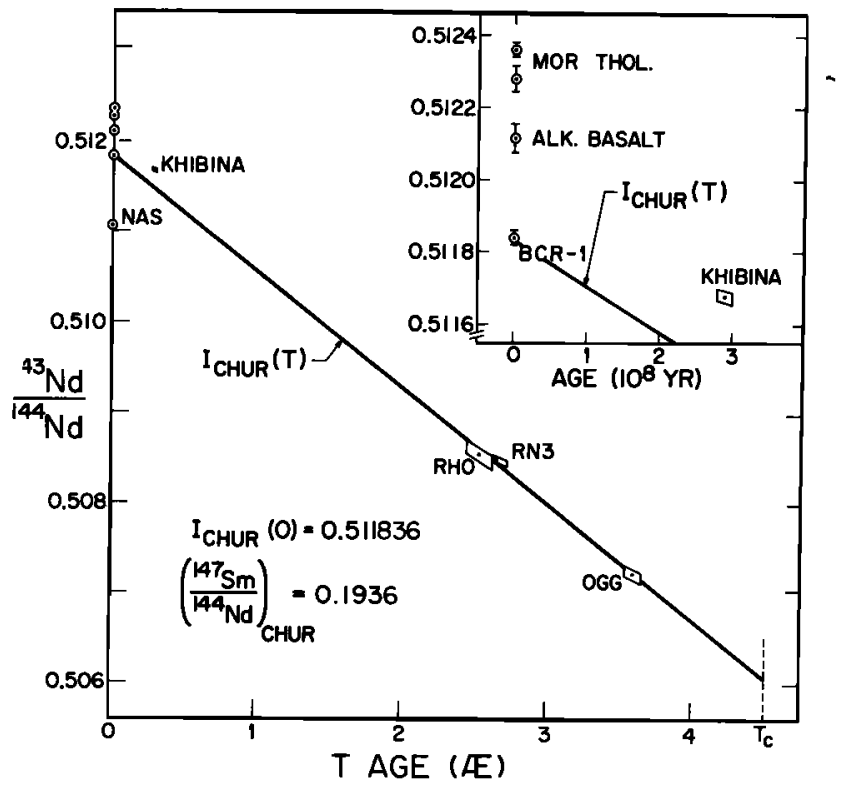

Fig. 2: Uoserved initial ${ }^{143} \mathrm{Nd} /{ }^{144} \mathrm{Nd}$ versus tıme. $\mathrm{I}_{\mathrm{CHUR}}(\mathrm{T})$ represents evolution of ${ }^{143} \mathrm{Nd} / /^{144} \mathrm{Nd}$ in a reservoir with chondritic $\mathrm{Sm} / \mathrm{Nd}$.

topic variations are small, so precise measurements and careful consideration will be necessary for their correct interpretation.

The data are given in Table 2 relative to a uniform reservoir whose characteristics are those of the Juvinas achondrite ( $L u g$ mair, 1974, pers. comm., and Lugmair et al., 1975b). These characteristics were chosen because Juvinas has $\mathrm{Sm} / \mathrm{Nd}$ very close to the average chondrite (0.308) (Masuda, 1973, c.f Lugmair, 1975c) and therefore must approximate a chondritic uniform reservoir (CHUR), allowing direct comparison of terrestrial data to that expected in a chondritic earth. Since this paper was first submitted, we have been informed (Lugmair, pers. comm.) of a revised best estimate for ${ }^{143} \mathrm{Nd} /{ }^{144} \mathrm{Nd}$ in Juvinas, which differs significantly from that reported by Lugmair (1974). The revised value is used here, so that $\mathrm{I}_{C \mathrm{CHIR}}(0)=$ 0.511836 (normalized to ${ }^{148} \mathrm{Nd} / 1^{144} \mathrm{Nd}=0.243082$ ) and $\left({ }^{147} \mathrm{Sm} /{ }^{144} \mathrm{Nd}\right){ }_{\text {CHUR }}^{0}=0.1936$. Model ages can be calculated relative to the initial value for Juvinas $\left(\mathrm{I}_{\mathrm{JUV}}=0.50598 \pm 10\right)$ (Lugmair, pers. comm.). The evolution of ${ }^{143} \mathrm{Nd} /{ }^{144} \mathrm{Nd}$ in CHUR and initial ratios for the samples are plotted in Fig. 2.

Results. The samples can be divided into two groups; zero age rocks and old rocks. The zero age suite consists of two mid-ocean ridge tholeiitic basalts of high Fe, Ti character (MOR Thol.; USNM 1 13152, USNM1 11240), one oceanic alkalic basalt (USNM113031) dredged near St. Pauls Rocks (Melson et al., 1967), and a continental basalt (BCR-1). Grouped with these are a sample of apatite ore from the Khibina nepheline syenite complex, USSR, and a composite of the North American shales (NAS) prepared by Paul W. Gast (cf. Haskin et al., 1966b). The old samples include a diabase from the Great Dyke, Rhodesia (RHO), a sample of the granodioritic Preissac-Lacorne batholith in the Superior Province of Canada (RN3), and a granodiorite Amitsoq gneiss sample from West Greenland (OGG). These samples have been well dated by other methods.

The four basalts and the apatite ore have small positive values of $\epsilon_{0}^{\text {CHUR }}$ indicating that they were derived from regions whose time-integrated $\mathrm{Sm} / \mathrm{Nd}$ is close to but somewhat higher than that of chondrites. The shale, however, has a large negative $\epsilon_{0}^{\text {CHUR }}$ which undoubtedly reflects the low Sm/Nd of average crustal rocks. The basalts, presumably derived from the mantle, indicate that a range of ${ }^{143} \mathrm{Nd} /{ }^{144} \mathrm{Nd}$ is now found there. The old samples all have low $\epsilon_{0}^{\text {CHUR }}$ values, representative of old lithic reservoirs with low $\mathrm{Sm} / \mathrm{Nd}$.

To evaluate ${ }^{143} \mathrm{Nd} /{ }^{144} \mathrm{Nd}$ in the mantle in the past a Great Dyke sample was chosen because its basaltic composition and mode of emplacement suggest derivation from the mantle. While it has $\epsilon_{0}^{\text {CHUR }}=-16.5$, its initial ratio lies within error on
CHUR at 2.53 AE (see Figure 2), and is strong evidence that the CHUR curve is indeed relevant to mantle evolution. The other two ancient samples have large negative values of $\epsilon_{0}^{\text {CHUR }}$. Although these rocks have no clear or direct relationship to the mantle, their initial ratios nonetheless also lie on CHUR within errors. For sample RN3, a two-point internal isochron (see tables) yields a Sm-Nd age of $2.64 \pm 0.13 \mathrm{AE}$, in agreement with the U-Th-Pb result (Steiger and Wasserburg, 1969).

The positions of initial ratios relative to the CHUR curve can be seen clearly in Figure 3. In general the data demonstrate that the earth has a chondritic $\mathrm{Sm} / \mathrm{Nd}$ to within $\sim 5 \%$. The variation of $\epsilon_{1}^{\text {CHUR }}$ in young basalts indicates the existence of isotopic heterogeneities in their source regions, a phenomenon which was previously known from $\mathrm{Pb}$ and $\mathrm{Sr}$ isotope variations (Gast, et al., 1964, Tatsumoto, 1966, Gast, 1968, and others). Oceanic tholeiite samples have the highest values of $\epsilon_{1}^{\text {CHUR }}$ and must be derived from sources with higher $\left\langle f_{s}\right\rangle$ than the other samples. The alkali basalt sample is clearly derived from a different reservoir than the tholeiites. BCR-1 has a much lower $\epsilon_{\mathrm{I}}^{\mathrm{CHUR}}$ than the oceanic samples, which may indicate gross differences between basalt source regions under continents and those under oceans. However BCR-1 could also have acquired a lower $\epsilon_{\mathrm{I}}^{\mathrm{CHUR}}$ through contamination from old crustal material. The range in $f^{*} T^{*}$ values for the young basalts indicates that for differences of $f$ in the sources of $\sim 0.1$, these sources must have been isolated for times $>1 \mathrm{AE}$.

Basalt 113031 has a low $\mathrm{Sm} / \mathrm{Nd}$ typical of alkali basalts, but its positive $\epsilon_{1}^{\text {CHUR }}$ is evidence that this oceanic alkali basalt is not derived from an ancient source region which is significantly enriched in LREE relative to chondrites. The Khibina apatite sample is from an alkalic complex strongly enriched in LREE (Balashov, 1963, cited in Haskin et al., 1966a), yet $\epsilon_{\mathrm{I}}^{\mathrm{CHUR}}$ is also positive. Thus this data strongly suggest that the highly fractionated REE patterns in alkali basalts and alkalic intrusions are the result of short-duration magmatic processes rather than the result of derivation from ancient, low $\mathrm{Sm} / \mathrm{Nd}$ source regions.

The fact that $\epsilon_{\mathrm{I}}^{\text {CHUR }}$ of the ancient granitic rocks is zero means that these rocks were derived essentially directly from a chondritic $\mathrm{Sm} / \mathrm{Nd}$ source. This implies derivation from mantle sources, since their $\epsilon_{\mathrm{I}}^{\mathrm{CHUR}}$ are identical with that of the Great Dyke sample. These data are not compatible with their derivation from much older, highly fractionated material. However, larger errors in $\epsilon_{1}^{\mathrm{CHUR}}$ for these samples, resulting from a sum of errors in $\epsilon_{0}^{\text {CHUR }}, \mathrm{f}_{R}$, and the age, when coupled with the smaller time interval $\left(\mathrm{T}_{\mathrm{C}}-\mathrm{T}\right)$ place weaker constraints on their sources.

Inspection of Figure 3 shows that the range of $\epsilon_{\mathrm{I}}^{\mathrm{CHUR}}$ in young samples is larger than in the ancient samples. This may result simply from the fact that the difference in ${ }^{143} \mathrm{Nd} /{ }^{144} \mathrm{Nd}$ in reservoirs with different $\mathrm{Sm} / \mathrm{Nd}$ grows with time. Alternatively, it may be indicative of a real difference in the degree of heterogeneity in the Archean mantle as compared to the modern mantle.

Partial melting generally produces a liquid with lower $\mathrm{Sm} / \mathrm{Nd}$

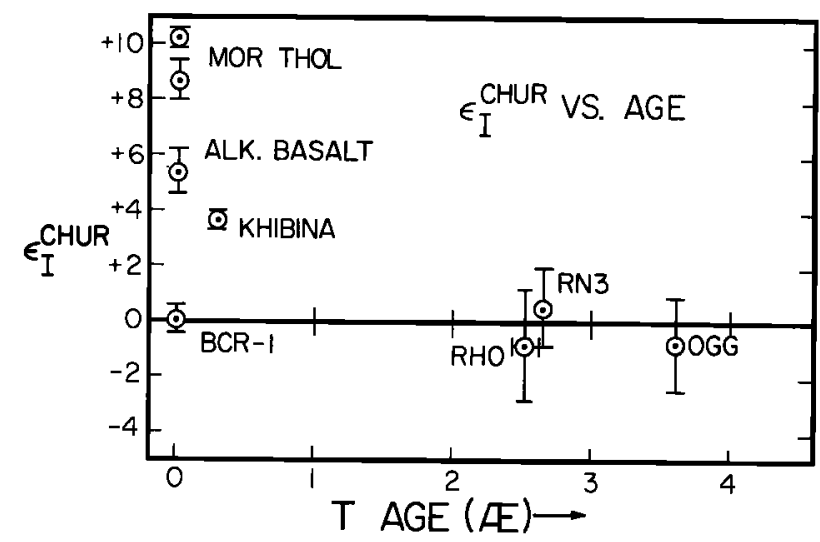

Fig. 3: Fractional deviations in parts in $10^{4}$ of initial ${ }^{143} \mathrm{Nd} /{ }^{144} \mathrm{Nd}$ from evolution in a chondritic $\mathrm{Sm} / \mathrm{Nd}$ reservoir (CHUR) vs. time. 
and a residue with higher $\mathrm{Sm} / \mathrm{Nd}$ than the starting material. This process tends to produce reservoirs with diverging ${ }^{14}{ }^{3} \mathrm{Nd} /{ }^{144} \mathrm{Nd}$. The crust, since it represents the earth's lowmelting fraction, must also contain the reservoirs of lowest ${ }^{143} \mathrm{Nd} /{ }^{144} \mathrm{Nd}$. If the $\mathrm{Nd}$ in the crust is a significant portion of that in the earth, then there must exist regions of the mantle with high ${ }^{143} \mathrm{Nd} /{ }^{144} \mathrm{Nd}$ corresponding to a high $\mathrm{Sm} / \mathrm{Nd}$ residue. The source regions of oceanic tholeiites, by virtue of their high ${ }^{143} \mathrm{Nd} /{ }^{144} \mathrm{Nd}$ are the best candidates for this residue. This is clearly consistent with trace element (Gast, 1968, Kay and Gast, 1973) and other isotopic data (Peterman and Hedge, 1971) which indicate that these basalts are derivatives of a mantle which has been left as a residue from previous partial melting. In order to classify mantle source regions as having increased or decreased $\mathrm{Sm} / \mathrm{Nd}$ on the basis of ${ }^{143} \mathrm{Nd} /{ }^{144} \mathrm{Nd}$, one needs precise knowledge of the bulk earth evolution curve. The CHUR curve appears to be a good first approximation.

The variation of $\epsilon_{1}^{\text {CHUR }}$ in the young basalts could be due to differences of $\mathrm{Sm} / \mathrm{Nd}$ in source regions formed near the time of formation of the earth, or to differences formed by continuous large-scale differentiation and fractionation over a long time scale from some homogeneous initial reservoir, to form secondary reservoirs from which basalts are ultimately derived. The data presently provide no clear-cut indication of which is the case. For instance, tholeiite sample USNM113152 has a model age of $4.50 \pm 0.07 \mathrm{AE}$. Using this datum, the model age of the source is $4.50\left(1+\mathrm{g} \mathrm{TH}_{\mathrm{TH}}\right) \mathrm{AE}$. If $\mathrm{g}_{\mathrm{TH}}=0$, then one would conclude that the source region was formed during a very early terrestrial differentiation, essentially at the time of formation of the earth. But if $\mathrm{g}_{\mathrm{TH}}<0$, then it is more likely that the source region for this basalt was generated in fractionation processes which occurred at least a few hundred million years after $T_{c}$.

If the isotopic composition and $\mathrm{Sm} / \mathrm{Nd}$ of the shale are representative of average North American crust, then from f* $\mathrm{T}^{*}$ we obtain $\mathrm{T}^{*}=1.5 \mathrm{AE}$. This can be taken to be the "mean" age of this crustal material, i.e., the time it was fractionated from the CHUR evolution curve.

Conclusions. From the data presented we conclude that the $\mathrm{Sm} / \mathrm{Nd}$, and by inference the REE abundance pattern of the earth, is equal to the average of chondritic meteorites to within a few percent. Variations in $143 \mathrm{Nd} /{ }^{144} \mathrm{Nd}$ in young basalts permits the identification of distinctive mantle sources and indicates the preservation of significant heterogeneities in the mantle for times of $\sim 1-4 \mathrm{AE}$. The isotopic data also show that mantle source regions with $\mathrm{Sm} / \mathrm{Nd}$ different by a factor of two from chondritic are not preserved for longer than a few hundred million years. Average continental crustal material has much lower ${ }^{143} \mathrm{Nd} /{ }^{144} \mathrm{Nd}$ than that found for the mantle, and reflects its low $\mathrm{Sm} / \mathrm{Nd}$, resulting from REE fractionation during formation of crust from the mantle.

Acknowledgments. We thank W. G. Melson, P. Vogt, G. Thompson, and L.A. Haskin for providing samples and K. Gschneider for providing high purity Nd metal (normal NN2). Technical assistance and advice from D. A. Papanastassiou, D. Curtis, and F. Tera were invaluable and are gratefully acknowledged. DJD would like to thank Arden Albee for steering him in the direction of this work. Precise $\mathrm{Pb}$ isotopic work by A.J. Gancarz (Gancarz, Tera, and Wasserburg, 1975) assured us of the antiquity of the Greenland sample collected by project Oldstone. This work represents a return to a problem first attempted using Rb-Sr by Paul W. Gast (Gast, 1955, 1960). This work was supported in part by NSF NPS 71-02670 AOS and NASA NGL 05002188. An outline of these results was published in E๑S (DePaolo and Wasserburg, 1976). Comments on our cryptography by cognizant colleagues, A. L. Albee, A. J. Gancarz, D. A. Papanastassiou and S. Jacobsen are hereby acknowledged. We appreciate the comments of G. Lugmair and his courtesy in making the revised Juvinas data available. Fhis is contribution No. 2730 of the Div. of Geological and Planetary Sciences.

\section{References}

Baadsgaard, H., U-Th-Pb dates on zircons from the early precambrian
Amitsoq Gneisses, Godthaab District, West Greenland, Earth Planet. Sci. Lett., 19, 22-28, 1973.

Boynton, W.V., Fractionation in the solar nebula: condensation of yttrium and the rare earth elements, Geochim. Cosmochim. Acta, 39, 569.584, 1975.

Davies, R. D., H. L. Allsopp, A. J. Erlank, and W. I. Marston, Sr., isotopic studies on various layered mafic intrusions in southern Africa, Spec. Publ. Geol. Soc. S. Africa 1, 576, 1970.

DePaolo, D. J. and G. J. Wasserburg, Nd Isotopic variations and Petrogenetic Models (abs.) E $\oplus$ S 57, 351 (1976).

Eugster, O., F. Tera, D. S. Burnett and G. J. Wasserburg, The isotopic composition of Gadolinium and Neutron capture effects in some meteorites, J. Geophys. Res. 75, 2753-2768, 1970.

Gancarz, A. J., F. Tera and G. J. Wasserburg, 3.62AE Amitsoq gneiss from West Greenland and a 4.45AE "Age of the Earth" (abs.) GSA Abs., $7,1081,1975$.

Gast, P. W., Abundance of $\mathrm{Sr}^{8} 7$ during geologic time, Bull. Geol. Soc. Am, 69, 1369-1410, 1955.

Gast, P. W., Limitations on the Composition of the Upper Mantle, J. Geophys, Res., 65, 1287-1297, 1960.

Gast, P. W., Trace element fractionation and the origin of tholeiitic and alkaline magma types, Geochim. Cosmochim Acta, 32, 1057-1086, 1968.

Gast, P. W., G. R. Tilton, and C. Hedge, Isotopic Composition of Lead and Strontium from Ascension and Gough Islands, Science, 145, 1181-1185, 1964.

Gerasimoysky, V. I., V. P. Volkov, L. N. Kogarko, and A. I. Polyakov, Kola Peninsula, 206-21, in Sorenson, Ed., The Alkaline Rocks. John Wiley and Sons, New York, 62p., 1974.

Haskin, L. A., F. A. Frey, R. A. Schmitt, and R. H. Smith, Meteoritic, Solar and Terrestrial Rare-Earth Distributions, Physics and Chemistry of the Earth, 7, 167-321, 1966.

Haskin, L. A., T. R. Wildeman, F. A. Frey, K. A. Collins, C. R. Keedy, and M. A. Haskin, Rare Earths in Sediments, J. of Geophys. Res, 71 . $6091-6105,1966$.

Kay, R. W., and P. W. Gast, The Rare Earth Content and Origin of Alkali-rich Basalts, Jour. of Geol., 81, 653-682, 1973.

Lugmair, G. W. Sm-Nd ages: a new datıng method (abs.), Meteoritics, 9 , 369,1974 .

Lugmair, G. W., N. B. Scheinin, and K. Marti, Sm-Nd age of Apollo 17 basalt 75075: Two-stage igneous processes in mare basalt genesis (abs.), Lunar Sci. VI, Lunar Sci. Inst., Houston, 531-53, 1975a.

Lugmair, G. W., N. B. Scheinin, and K. Marti, Search for Extinct ${ }^{146} \mathrm{Sm}$, 1. The isotopic abundance of ${ }^{142} \mathrm{Nd}$ in the Juvinas meteorite, Earth. Plan. Sci. Lett., 27, 79-84, 1975 b.

Lugmair, G. W., N. B. Scheinin, and K. Marti, Sm.Nd Age and History of Apollo 17 Basalt 75075: Evidence for early differentiation of the lunar exterior, Proc. Lunar. Sci. Conf. 6th, 1419-1429, 1975c.

Lugmair, G.W., N. B. Scheinin, Sm-Nd Systematics of the Stannern Meteorite, Meteoritics 10, 447.448, 1975.

Masuda, A., N. Nakamura, T. Tanaka, Fine structures of mutually normalized rare-earth patterns of chondrites, Geochim. Cosmochim. Acta., 37, 239-248, 1973.

Melson, W. G., E. Jarosewich, R. Cifelli, G. Thompson, Alkali Olivine Basalt dredged near St. Paul's Rock, Mid-Atlantic Ridge, Nature, 215, 381-382, 1967.

Nier, A. O., A redetermination of the relative abundances of the isotopes of carbon, nitrogen, oxygen, argon, and potassium, Phys. Rev., 77, 789.793, 1950 .

Peterman, Z. E. and C. E. Hedge, Related Strontium Isotopic and Chemical Variations in Oceanic Basalts, G.S.A. Bull, 82, 493-500, 1971.

Steiger, R. H. and G. J. Wasserburg, Comparative U-Th-Pb systematics in $2.7 \times 10^{9}$ yr plutons of different geologic histories, Geochim. Cosmochim. Acta, 33, 1213-1232, 1969.

Tatsumoto, M., Isotopic composition of lead in volcanic rocks from Hawaii, Iwo Jima, and Japan, J. Geophys. Res., 71, 1721-173, 1966.

Wasserburg, G. J. D. A. Papanastassiou, E. V. Nenow, and C. A. Bauman, A Programmable Magnetic Field Mass Spectrometer with On-line Data Processing, Rev. Sci. Instr. 40, 288-295, 1969.

Wasserburg, G. J. and D. A. Papanastassiou, Model Ages, Nature, 259, 159, 1975. 